\title{
ANALYSIS OF STUDENT RESPONSES IN LEARNING WITH ANDROID-BASED MEDIA
}

Falasifah Hasyim Chosi, Malia Fransisca, M.Pd.i

Mahasiswa Program Studi Ilmu Al-Qur'an Dan Tafsir, Fakultas Ushuluddin Adab dan Humaniora Univesitas Prof KH. Saifuddin Zuhri, Purwokerto

fala.sifa97@gmail.com, maliafransisca2018@gmail.com

\begin{abstract}
The author will try to do research by developing android-based interactive learning media on BTA learning materials, the author wants to try to find out the response of UIN SAIZU students to the learning media. This study aims to determine student responses to android-based interactive learning media at UIN SAIZU by using the observation method and learning test results. Data collection teaching. The results of the study were obtained based on the results of students' responses to learning media based on Android on BTA material getting an average percentage of $78.21 \%$ in the first observation test with good categories and observation test. The research will try to prove that Android-based BTA learning is very effective because it can be used for all circles, both students and people who are very busy because learning can be done anywhere besides being practical, Android can be used for all positive things. conclusions can be drawn from this discussion as follows:

a) Applications for learning tajwid based on android can be used by Muslims as an alternative to learning tajwid independently.

b) With the application of learning tajwid which is equipped with examples of images and sounds, as well as quizzes to test abilities, users are expected to be able to maximize this mobile application as a medium for learning tajwid that is easy to use and easy to reach.

c) Tajweed science applications can be run via smartphones with the Android operating system.

d) The application of tajwid is made using the Java programming language and designed with an easy display.
\end{abstract}

Keywords: developing android-based interactive learning

\section{PRELIMINARY}

In this very sophisticated era, the development of science and technology is changing very rapidly from time to time. Especially in the world of education, a teacher is required to be able to make reform efforts related to technological advances in teaching and learning activities. One of the efforts to utilize technology is the learning process with android-based media. The use of this media is highly recommended because of community conditions related to the COVID case that has hit our country lately. As a result, this Android-based learning process is even considered very flexible and considered very efficient.

The application of the first BTA learning regarding Tajwid Science is very much required for students who want to improve their reading of the Qur'an using the tajwid learning method. The existence of a learning system using Android will greatly facilitate students in learning, applications that are loaded on Android are now very complete as well as listening to the applications used, making it easier for Muslims, especially students who have limited time to learn easily and can be used anytime, considering the android technology that has been widely used. In addition, users can measure their learning abilities with practice questions that are already available. ${ }^{1}$

Along with the high level of mobility, in the last few years mobile devices have emerged. One of the fastest mobile devices is a cell phone, where almost everyone has it. Mobile, which is

\footnotetext{
${ }^{1}$ Ma'arif, Vadlya jurnal (Aplikasi Pembelajaran Ilmu Tajwid Berbasis Android)
} 45 | الطموحات - السنة الثالثة، العدد الثاني، أغسطس 2020 available at: http://journal.uir.ac.id/index.php/THUMUHAT 
used as a communication tool, is now more than its basic function. Various kinds of features have been embedded, such as image and video processing, document processing and so on. This is inseparable from the use of the operating system on the cellphone. Just like on a computer, a cell phone can also be installed with various kinds of desired applications.

One of the operating systems used in various mobile devices is Android. Android has the main goal of advancing mobile phone innovation so that users can explore capabilities and add more experiences compared to other mobile platforms. Until now, Android continues to grow, both in terms of systems and applications. This makes people, both parents, teenagers and children, already use mobile phones with the Android operating system in their daily lives because they are very easy to get and the price is also very affordable.

Therefore, one solution that can be taken is to develop an android-based tajwid science application $^{2}$. In the world of education, this application can be used as an additional study guide to support the learning process. The development of an Android-based tajwid application will help increase interest and also make it easier for Muslims, both children, teenagers and parents who want to learn about tajwid independently, whenever and wherever they are without feeling ashamed because they are too mature or too old to learn. study.

Based on the above background, researchers are interested in conducting research on analyzing student responses to android-based learning media on BTA material. This study aims to determine student responses to android learning media in BTA subjects.

\section{METHOD}

The methods used in this study are:

1. Observation method, carried out by observing directly the learning activities of tajwid which are carried out at the TPA (Al-Qur'an Educational Park).

2. The interview method is a question and answer process directly to parties directly related to the learning activities of tajwid. 3. Literature study, in this method a literature study is carried out or looking for references from books, journals or literature related to the science of recitation and the application of tajwid science.

\section{RESULTS AND DISCUSSION}

\section{Case Review}

Tajwid according to language (ethimology) is to beautify something. Meanwhile, according to the term is removing each letter from the place of its exit (mahroj) by giving rights and mustahaknya. What is meant by letter rights is the original nature that is always with the letter, such as al-jahr, isti'la, istifal, while mustahak letters are characteristics that appear from time to time, such as tafkhim, tarqiq, ikhfa. Broadly speaking, tajwid is a science that teaches how to read the Qur'an properly and correctly. The purpose of tajwid is to protect the reading of the Qur'an from errors and changes and to maintain the oral (mouth) from reading errors.

Islam teaches that reading the Qur'an is a form of worship. Good and correct reading of the Qur'an is one of the conditions for the perfection of prayer. The Messenger of Allah (SAW) said: "Those who recite the Qur'an proficiently will one day have a place in Paradise with the noble Messengers. Whereas people who read the Qur'an but are not proficient, read it stunned and not fluent, he will get two rewards ". (History of Bukhari and Muslim from St. Aishah ra.)

Basically, as Muslims, we must understand and understand the importance of studying the science of recitation of the Qur'an in order to know the procedures for reading the Qur'an with tartil, fluently, knowing that a lafazh must be spelled out. read long, know the rights of letters and their properties. Many Muslims are new to learning the Qur'an and Hadith.

\footnotetext{
${ }^{2}$ Wati Rahayu jurnal (Aplikasi Pembelajaran Ilmu Tajwid Berbasis Android)
} 


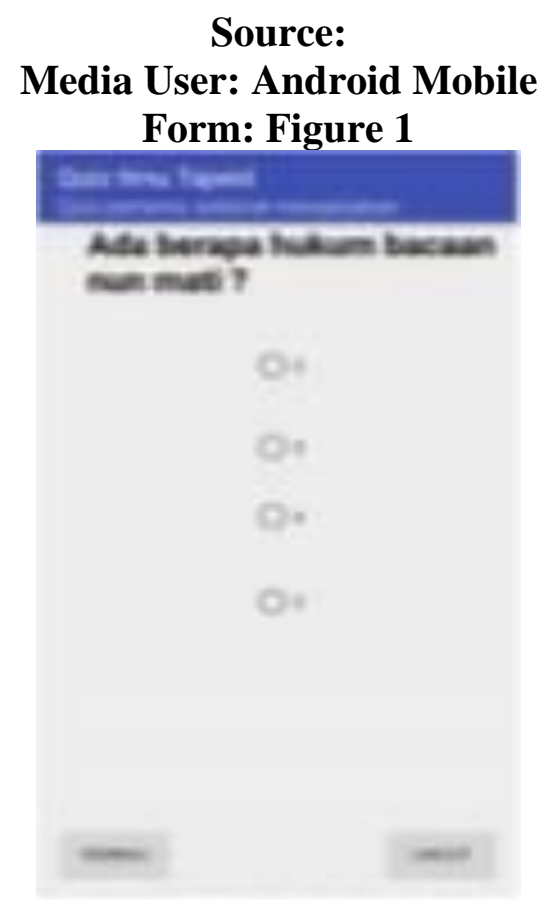

Figure 1. Input Form

a) Output Form Specifications The output

data used in the application of tajwid are as follows:

Document Name: Quizpertama.xml

Function: To display the quiz results in the form of text messages.

If the answer is wrong, a text message "Your answer is wrong", if the answer is correct, a dialog "Congratulations!!!" will appear. Your answer is correct" and also the "REPEAT" button to repeat the question, and the "OK" button which will display the text message "Congratulations".

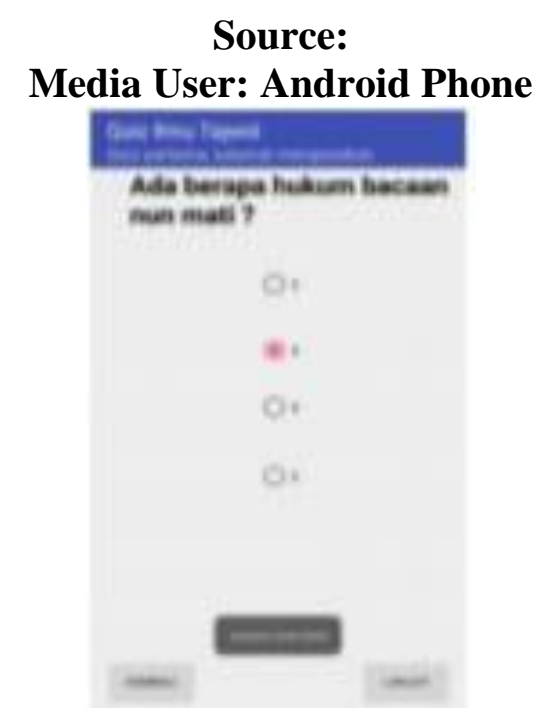

Shape: Figure 2 and Figure 3

b). Main Menu

Program Name: MainActivity.java 
Function: An activity that contains other program parts.

Program Language: Java

Display Format: Figure 5

Process: The main menu will run immediately when the program is opened by the user.

c) Menu Instructions

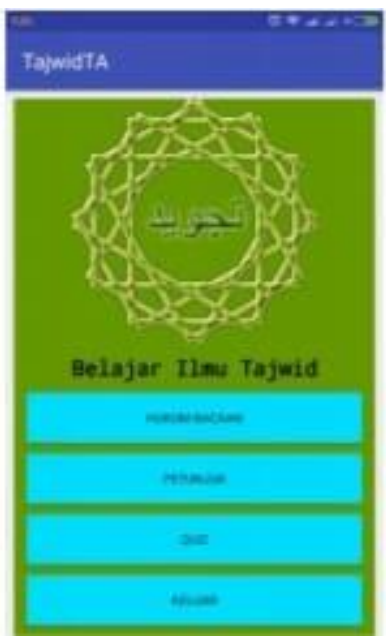

Figure 6. Main Menu Display

Program Name: Instructions.java

Function: To display information on application usage instructions.

Program Language: Java

Display Format: Figure 6

Process: If you press the "Hints" menu, you will go to the instruction's information page.

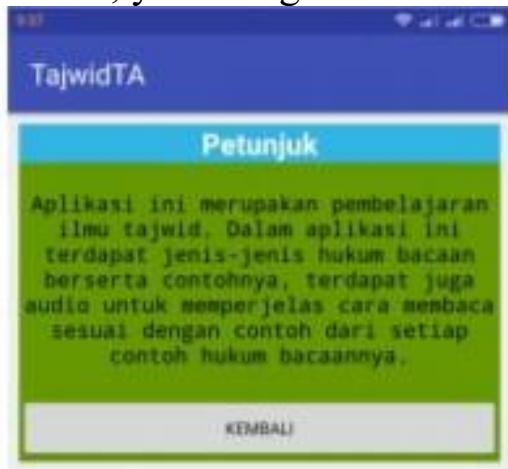

Figure 7. Instructions

d) Quiz Menu

Program Name: Quizpertama.java

Function: Is a guide to use the application.

Program Language: Java

Function: Is an activity that displays the contents of Izhar.

Program Language: Java

Display Format: Figure 9

Process: If you press the "Izhar" menu, a description of Izhar will be displayed along with examples of images and sounds. 


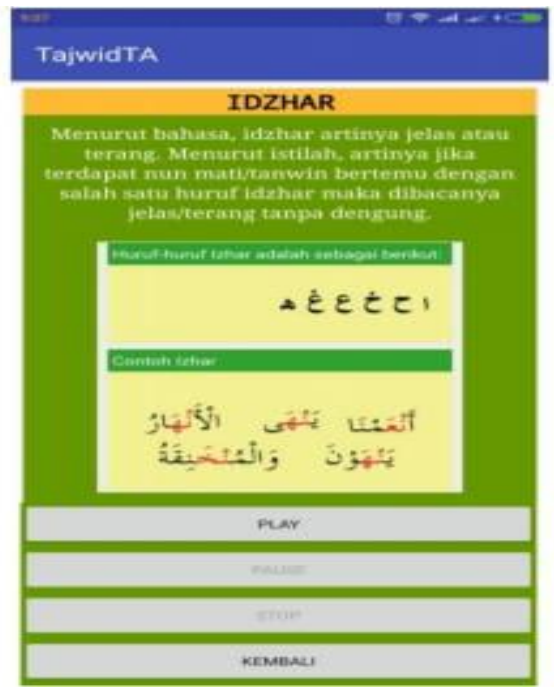

Figure 10. Izhar

Program Design Specifications

The following is about how the application works in general:

a) In this application there are 4 menus, namely the reading law menu where in this menu there are types of reading law. Instructions menu, in this menu there are instructions for using the application of tajwid. Quiz menu, in this menu the user can work on the available quizzes. And exit menu to exit the application.

b) The reading law menu will display the types of reading laws such as the law of reading dead, mim dead, mad, qalqalah and waqaf.

c) The quiz menu will display questions and answer choices, after selecting an answer, the user will immediately know whether the answer is right or wrong through a text message that appears after choosing an answer.

Input Form Specifications

The data entered by the user in the tajwid science application are as follows:

Document Name: Quizpertama.xml

Function: To select the answer from the displayed questions

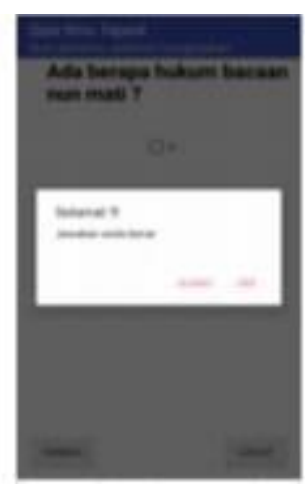

Figure 3. The output form when the selected answer is correct

Program Specifications

The specifications for this tajwid science application program are as follows:

a) Menu Opening

Program Name: SplashScreen.java 
Function: Is an application opening program

Program Language: Java

Display Format: Figure 4

Process: The first page that appears when the application is opened, the initial display is the title of the application.

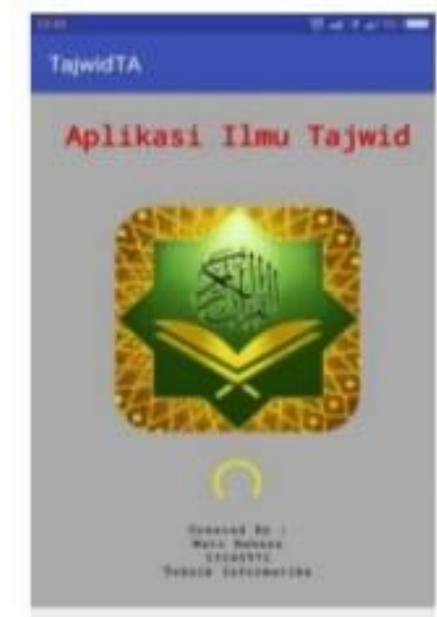

Figure 5. Display Splash screen

Menu Nun Mati/ tanwin

Program Name: NunMati.java

Function: It is an activity that contains menus for reading the law of nun mati/ tanwin.

Program Language: Java

Display Format: Figure 8.

Process: If you press the "Nun Mati" menu it will display the menus for the law of non-death reading, namely idzhar, idghom, ikhfa', iqlab and the back button to return to the reading law menu.

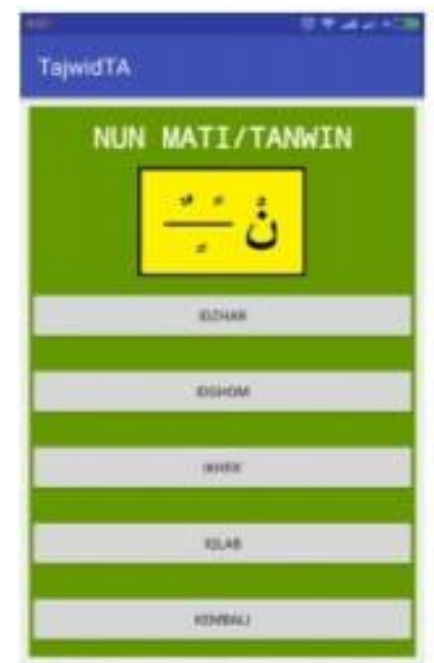

Figure 9. Nun Mati/Tanwin

\section{CONCLUSION}

Based on the discussion and the results obtained, it can be concluded as follows:

a) Android-based tajwid learning applications can be used by Muslims as an alternative to learning tajwid independently. 
b) With the application of learning tajwid which is equipped with examples of images and sounds, as well as quizzes to test abilities, users are expected to be able to maximize this mobile application as a medium for learning tajwid that is easy to use and easy to understand.

c) Tajwid science applications can be run via smartphones with the Android operating system.

d) The application of Tajwid is made using the Java programming language and is designed with an easy-to-understand interface.

Learning to read and write the Qur'an is very important and must be considered in order to be able to determine especially the learning of the Qur'an. One of them is BTA learning about Tajwid which has been described above.

\section{REFERENCE}

Ma'arif, Vadly. 2018. APLIKASI PEMBELAJARAN ILMU TAJWID BERBASIS ANDROID. Jakarta: Nusa Mandiri.

Kurniawan, Agung 2010. METODE PEMBELAJARAN BTA TERHADAP KEMAMPUAN MEMBACA AL-QUR'AN. Jakarta: Ciledung Tangerang.

Herlina. 2017. PEMBELAJARAN BACA TULIS AL-QUR'AN(BTA)UNTUK MEINGKATKAN AKHLAK DAN MORAL PADA ANAK USIA DINI. Palembang.

Harnanto, Anwar Dwi. 2013." Pembuatan Aplikasi Pendukung Pembelajaran Bahasa Isyarat Pada Anak Berkebutuhan Khusus". Skripsi. Surakarta: Fakultas Komunikasi dan Informatika Jurusan Teknik Informatika. Universitas Muhammadiyah Surakarta. $<$ http://etd.eprints.ums.ac.id/26127/15/Naskah_Publikasi.pdf $>$

Hidayat, Ade Kusuma. 2013. "Aplikasi Pembelajaran Materi Dasar Taman Kanak Kanak Berbasis Android". Jurnal Transit Volume 1, Nomer 3. Semarang: Universitas Semarang. $<$ http://journal.usm.ac.id/elibs/USM_0d97jurnal\%20ade\%20kusuma\%20hida yat3-8.pdf > Ismail, Achmad Zainuddin. 2020. METODE PEMBELAJARAN BACA TULIS AL-QUR'AN DI SMP NEGRI UNGGARAN. Unggaran: Kauman Selatan.

Nugroho, Fuad Rajab. 2013. "Rancang Bangun Aplikasi Streaming Education Pada Perangkat Bergerak Berbasis Android”. Skripsi. Semarang: Fakultas Teknik Jurusan Teknik Elektro. Universitas Diponegoro. $\quad<$ http://www.elektro.undip.ac.id/el_kpta/wp-content/uploads /2012/05/L2F309047_MTA.pdf >

Pamuji, Eko. 2013. "Pembuatan Aplikasi Pembelajaran Andromath Berbasis Android". Skripsi. Yogyakarta: Jurusan Sistem Informasi. Amikom Yogyakarta. $<$ http://repository.amikom.ac.id/files/Publikasi_08.12.2980.pdf >

Safaat, Nazruddin. 2012. PemrogramanAplikasi Mobile Smartphone Dan TabletPCBerbasis Android. Bandung. Informatika Bandung. Wahana Komputer. 2013. Android Programming with Eclipse. Semarang. Penerbit Andi. >

Wijayanto, Chris Putut. 2009. "Membangun Aplikasi Pelatihan Bahasa Isyarat Berbasis Komputer Pada Orang Tuna Rungu". Skripsi. Amikom Yogyakarta. $<$ http://journal.amikom.ac.id/index.php/D3TI/article/downloadSuppFile/227 